\title{
Dos Manuscritos da Aritmética Elementar de Charles S. Peirce: uma breve apresentação e algumas considerações sobre sua tradução
}

\author{
Peirce's Primary Arithmetics: a brief presentation and some remarks on \\ the translation of these manuscripts to Portuguese
}

\author{
Antonio Vicente Marafioti Garnica* \\ ORCID iD 0000-0003-0750-8483 \\ Leandro Josué de Souza** \\ ORCID iD 0000-0003-0441-4414 \\ Maria Ednéia Martins Salandim*** \\ ORCID iD 0000-0002-4866-9577
}

\begin{abstract}
Resumo
O artigo apresenta, um a um, os cinco manuscritos que compõem o que se pode chamar da Aritmética Elementar de Charles Sanders Peirce, quais sejam, aqueles chamados: Aritmética Elementar de Lydia Peirce, Aritmética Elementar (com sugestões para professores), Aritmética Elementar de Peirce (Sobre o Método Psicológico), Aritmética Elementar de C. S. Peirce e suas principais características, e Aritmética Prática. Traz, também, algumas considerações acerca da primeira tradução desses textos para a língua portuguesa e de alguns aspectos da trajetória dos escritos de Peirce, publicados ou não, até que projetos específicos de sistematização e publicação fossem criados. Assim, este texto trata de arrematar uma hermenêutica inicial já iniciada em outros textos dos mesmos autores.
\end{abstract}

Palavras-chave: Charles Sanders Peirce. Aritmética Elementar. Tradução. Educação Matemática. História.

\begin{abstract}
This paper aims to present the five manuscripts of the so-called Peirce's Primary Arithmetics (Lydia Peirce's

\footnotetext{
* Doutor em Educação Matemática pela Universidade Estadual Paulista "Júlio de Mesquita Filho" (UNESP), Rio Claro/SP. Docente do Departamento de Matemática da UNESP, Bauru, São Paulo, Brasil e dos Programas de Pós-graduação em Educação Matemática UNESP, Rio Claro, São Paulo, Brasil e Educação para a Ciência UNESP, Bauru, São Paulo, Brasil. Endereço para correspondência: Avenida Nações Unidas, 11-35/1101, Bauru, Sao Paulo, Brasil, CEP: 17010-130. E-mail: vgarnica@ fc.unesp.br.

${ }^{* *}$ Mestre em Educação para a Ciência pela Universidade Estadual Paulista "Júlio de Mesquita Filho" (UNESP), Bauru/SP. Endereço para correspondência: Vila Operária, 78, Olaria, Nova Friburgo, Rio de Janeiro, Brasil, CEP: 28620-030. E-mail: leandrojosue@ gmail.com.

*** Doutora em Educação Matemática pela Universidade Estadual Paulista "Júlio de Mesquita Filho" (UNESP), Rio Claro/SP. Docente do Departamento de Matemática da UNESP, Bauru, São Paulo, Brasil e do Programa de Pós-graduação em Educação para a Ciência UNESP, Bauru, São Paulo, Brasil. Endereço para correspondência: Avenida Luis Edmundo C. Coube, s/n, Departamento de Matemática, Bauru, São Paulo, Brasil, CEP: 17033360. E-mail: edsalandim@ fc.unesp.br.
} 
Primary Arithmetic; Primary Arithmetic (with suggestions to teachers); Peirce's Primary Arithmetic upon the psychological method; C.S.Peirce's Vulgar Arithmetic: its main features, and Practical Arithmetic) and to sketch some remarks on the process of translating such manuscripts to Portuguese. This article is the last study related to some initial and brief hermeneutics already started in the other articles published by the same authors.

Keywords: Charles Sanders Peirce. Primary Arithmetics. Translation. Mathematics Education. History.

\section{Introdução}

Não foram poucos os textos publicados, em vida, por Charles Sanders Peirce (18391914), mas, certamente, são em número bem maior os manuscritos inéditos deixados por ele, como anotações, registros, diários, cartas, listas, textos completos e textos inacabados. Edward C. Moore ${ }^{1}$, no prefácio de Peirce (1982), faz uma projeção de que as publicações de Peirce equivaleriam a cerca de 24 volumes de 500 páginas cada, já os manuscritos não publicados equivaleriam a 80 outros volumes. Essas tantas páginas não publicadas, segundo Brent (1998), um dos biógrafos de Peirce, foram elaboradas a partir de 1884, após sua saída da Johns Hopkins University², até 1914, ano de sua morte.

Houser (1998) destaca que foi no ano de 1914 que os manuscritos de Peirce iniciaram sua viagem em direção ao Departamento de Filosofia de Harvard. Os documentos eram um emaranhado de papéis muitíssimo desorganizados, como o próprio Peirce reconheceu em um de seus manuscritos, afirmando que nem ele próprio seria capaz de organizar esses fragmentos.

Apenas em meados da década de 1930, Charles Hartshorne, juntamente com Paul Weiss, conseguiu editar seis volumes com parte desses manuscritos, então publicados pela Harvard University Press, entre 1935 e 1937, sob o título de Collected Papers of Charles Sanders Peirce, hoje considerados um marco para a filosofia americana. Mais dois volumes foram editados por Arthur Burks, em 1958, e agregados aos de Hartshorne e Weiss, estimulando o estudo a respeito do pensamento peirceano.

Já havia passado mais de uma década da publicação inicial dos Collected Papers quando Carolyn Eisele foi convidada a ministrar a disciplina de História da Matemática no Hunter College, onde era professora desde 1923. Eisele nasceu em Nova York, em 1902. Seus estudos em pós-graduação foram realizados na Columbia University, onde teve contato com o

\footnotetext{
${ }^{1}$ Edward C. Moore (1917-1993) foi diretor fundador do Peirce's Edition Project, da Indiana University Purdue University at Indianapolis, responsável pela publicação integral da obra de Peirce.

${ }^{2}$ A Johns Hopkins University, criada em 1976, foi a primeira escola de pós-graduação dos Estados Unidos (PEIRCE, 1958), sendo, inclusive, a primeira instituição de pesquisa real que existiu no país, e seu sucesso é atribuído a Daniel Coit Gilman, seu primeiro presidente.
} 
professor David Eugene Smith, que fora professor do Teachers College $e^{3}$ e era conhecido por seus trabalhos em História da Matemática.

Além de ter publicado livros sobre o assunto, havia traduzido originais de Descartes e de Felix Klein para o público americano. Até onde se sabe, esse parece ter sido o primeiro contato de Carolyn Eisele com os estudos em História da Matemática, tema que a acompanharia durante toda sua carreira. Eisele especializou-se em Matemática e Educação, com ênfase em História da Matemática. Sem a possibilidade de doutorar-se pela Columbia que à época não oferecia doutorado para mulheres - frequentou a University of Chicago e, mais tarde, a University of Southern California, sem, no entanto, ter concluído seu doutoramento devido a problemas familiares (seu pai acidentou-se, o que exigiu seus cuidados). Mesmo nunca tendo concluído o doutorado, foi professora do Departamento de Matemática e Estatística do Hunter College, de 1923 até sua aposentadoria. Seu reconhecimento profissional veio a partir de seus estudos sobre Charles Sanders Peirce.

Após a Segunda Guerra Mundial, quando já contava com uma experiência de 25 anos como professora universitária, Eisele foi convidada a lecionar a disciplina de História da Matemática. Visando preparar-se para essa função, valeu-se de uma licença sabática de um semestre para buscar fontes específicas na Columbia University - que, já à época, possuía um prestigiado arquivo sobre esse assunto. Foi naquele período, segundo seus biógrafos (GLEASON; DAUBEN, 2004), que Eisele descobriu um livro sobre o Liber Abaci, de Fibonacci, do século XIII, com anotações de Charles Sanders Peirce.

Os comentários desse autor, aparentemente, a impressionaram de uma tal maneira que ela decidiu escrever sobre essa sua descoberta, julgando que Peirce, autor das anotações, mereceria pesquisa mais detalhada. Seu artigo foi bastante bem recebido, do que resultou um convite, feito a ela pelo editor científico da Princeton University Press, para publicar um livro sobre Charles Sanders Peirce, com o que se aprofundou seu interesse por esse autor, que ela ajudou a estabelecer como um filósofo profundamente comprometido com a Matemática e com a História da Ciência, já que, até então, Peirce era mais conhecido por seu vínculo com o Pragmatismo ${ }^{4}$. Financiada pela American Philosophical Society, em 1954 Eisele publica um

\footnotetext{
${ }^{3}$ O Teachers College é uma prestigiada unidade da Columbia University, a primeira e maior Escola de Educação dos Estados Unidos.

${ }^{4}$ Em sentido amplo, o pragmatismo é a teoria do significado, ou melhor, sobre como fazer uma afirmação acerca do significado de algo. Como o fundador do Pragmatismo, Peirce, mais tarde, altera o nome de sua teoria para Pragmaticismo, em uma tentativa de diferenciá-la da de William James (PEIRCE, 1998). Uma das razões que o levou a esse afastamento era sua desconfiança em relação ao subjetivismo, que, segundo ele, tingia todas essas filosofias (PEIRCE, 1958). Para Peirce a verdade de qualquer afirmação deve ser avaliada a partir de suas
} 
artigo sobre Peirce no anuário da American Philosophical Society intitulado Peirce and the History of Science.

Em 1973, Max Fisch - que, com a ajuda de estudiosos como Carolyn Eisele, finalmente conseguiu impor uma ordem aos Manuscritos, de modo que eles pudessem ser efetivamente usados e citados pelos pesquisadores - apresenta a proposta de uma edição cronológica dos manuscritos peirceanos no que chamou de Um Plano para uma Nova Edição dos Escritos de Charles Sanders Peirce. Em 1975, o desenvolvimento desse Plano passou a ser de responsabilidade da Indiana University. Max Fisch foi designado como editor geral do projeto e, em 1976, o Peirce's Edition Project iniciou os trabalhos (HOUSER, 1998).

O Projeto intencionava criar uma edição crítica definitiva, organizando cronologicamente os escritos de Peirce. Coleções como os Collected Papers e o The New Elements of Mathematics, ainda que não sejam definitivas, estão na gênese desse Projeto que, hoje sediado em Indianapolis, pretende registrar o desenvolvimento e a coerência do pensamento peirceano, fornecendo um contexto que pode trazer novos significados para toda essa produção.

Em 1976, pela primeira vez, os manuscritos matemáticos de Peirce, do final do século XIX, foram tornados públicos por Carolyn Eisele, numa compilação de quatro volumes que, ainda hoje, é fonte obrigatória sobre a produção matemática de Peirce. O The New Elements of Mathematics by Charles S. Peirce (NE) ${ }^{5}$, editado por Eisele, contém os estudos sobre Aritmética, Álgebra, Geometria e algumas considerações sobre Filosofia da Matemática. Dentre entre esses manuscritos estão cinco pequenos textos que seriam publicados como um manual didático (ou uma série de manuais didáticos) para as escolas americanas de primeiras letras, dos quais fazem parte, também, guias didático-pedagógicos para professores. Como todos os manuscritos de Peirce, esses textos da Aritmética Elementar foram maltratados pelo tempo e, principalmente, pelo descuido dos que por eles eram, à época, responsáveis.

Para a classificação dos manuscritos (MS), Eisele segue a numeração dos textos originais da Coleção Peirceana da Houghton Library, de Harvard. Assim, o Manuscrito 189 (MS 189) - Aritmética Elementar de Lydia Peirce -, os MS 181 e 182 - Aritmética Elementar (com sugestões para professores) -, parte do MS 179 - Aritmética Elementar de Peirce (Sobre o Método Psicológico) -, o MS 178 - Aritmética Elementar de C. S. Peirce e suas

consequências práticas e suas relações com os interesses humanos, ou seja, os conceitos precisam ser compreendidos de acordo com suas implicações práticas (PEIRCE, 1998).

${ }^{5}$ O The New Elements..., para fins de citação em outras coletâneas peirceanas, como é o caso do Peirce's Chronological Edition, da Indiana University, é classificado como NE, e numerado de 1 a 4. 
principais características -, e o MS 168 (ao qual foram agregados exemplos disponíveis no MS 167) - Aritmética Prática -, formam um conjunto de textos que poderíamos chamar de Aritmética Elementar. Segundo Eisele, Peirce tinha em mente, naquele tempo, também uma Aritmética Avançada, no qual ele, provavelmente, desenvolveria tópicos de Teoria dos Números, como ele próprio afirmara em outros Manuscritos (NE1, p. xxxv). Essa Aritmética Superior ou Avançada, embora tenha sido projetada, nunca foi escrita ou, se o foi, nunca foi encontrada.

Dessa sistematização de Eisele provêm os textos que usamos como base para a tradução dos Manuscritos da Aritmética Elementar de Peirce que este artigo, em linhas gerais, tem a intenção de discutir. Uma hermenêutica completa dos manuscritos é um exercício impossível de realizar em um único artigo, e disso decorreu nossa opção por, além da publicação da tradução integral (GARNICA; SOUZA, 2018), divulgar dois artigos separadamente sobre esse mesmo tema. No primeiro deles (SOUZA; GARNICA; SALANDIM, 2018), apresentamos o que se pode chamar de uma análise sócio histórica dos manuscritos, discutindo aspectos tanto da biografia de Peirce e do contexto americano ressaltados os vieses social, político, cultural e educacional - do final do século XIX e início do século XX, quanto da história da própria elaboração e trânsito dos Manuscritos até sua sistematização por Eisele.

Neste segundo artigo, tratamos mais especificamente da tradução dos manuscritos para a língua portuguesa, e apresentamos, com maior detalhamento, cada um dos textos da Aritmética Elementar, ainda que não seja possível dar conta, aqui, de uma hermenêutica mais detalhada deles. Ambos os artigos, obviamente, interagem a todo momento, tanto entre si quanto com a íntegra da tradução, mas nem mesmo o conjunto dessas três produções resulta no que chamaríamos de uma hermenêutica, ainda que, segundo cremos, em seu conjunto eles sejam um esboço bem alinhavado para isso.

\section{Os manuscritos da Aritmética Elementar: sua tradução}

No prefácio do The New Elements of Mathematics by Charles Sanders Peirce, Carolyn Eisele conta que, àquela época, nos anos de 1970, muitos estudiosos acreditavam que o trabalho a partir dos manuscritos peirceanos havia se esgotado, não mais merecendo atenção, pois já haviam sido produzidos tanto o Collected Papers quanto o livro de Murray G. Murphey, Developments of Peirce's Philosophy. 
Em duas das introduções à sua obra - a Introdução Geral e a Introdução ao Primeiro Volume -, Eisele diz ter tentado, apenas, apresentar de modo claro, sem avaliar criticamente, a produção matemática de Peirce. Ela afirma que, quando preparando os materiais para a publicação, tentou restringir ao máximo tanto o número de notas de rodapé - julgando que a leitura do texto traria as respostas do próprio Peirce para muitas questões - quanto as interferências acerca da pontuação e da ortografia nos Manuscritos, pois ele atentava a alguns princípios psicológicos relativos à pontuação, especialmente quanto ao uso da vírgula, acreditando ser a prática da ortografia uma espécie de tirania.

Deve-se considerar, entretanto, que Eisele tinha disponíveis originais em sua própria língua, alguns datilografados, outros escritos à mão, e a eles deu uma forma organizada, impressa e tão homogênea em sua apresentação quanto foi a ela possível. Assim, sendo nossa intenção estudar esses manuscritos, pensamos em começar esse estudo por uma tradução para a língua portuguesa ${ }^{6}$.

Concordando com Eco (2014), entendemos a tradução como uma tentativa, já em princípio fracassada, de falar quase a mesma coisa que o autor da obra original, entendendo, também, que, ao tentar fazer isso, é preciso levar em consideração, muito cautelosamente, as várias nuanças do texto que podem ter e/ou têm, muitas vezes, características específicas que nos auxiliam a compreender a relação texto-autor. Às notas de Eisele incluímos algumas poucas notas nossas, e a diferenciação entre umas e outras deu-se por indicações do tipo NE para Notas da Editora (no caso, Carolyn Eisele) e NR para Notas do Revisor.

Como recomendado pela própria Eisele, não atualizamos informações que pudessem ter valor histórico (como informações relativas a moedas e à geografia, por exemplo) e incorporamos Notas do Revisor, alertando os leitores quando alterações mais distantes das traduções diretas do original foram necessárias. Dadas algumas particularidades da língua inglesa e alguns jogos que Peirce faz entre contagem e rimas infantis, as adaptações mais livres foram muito frequentes.

Além disso, por tratar-se de um texto de Matemática, julgamos necessário discutir certos conceitos específicos, visando à divulgação da versão em língua portuguesa para um

\footnotetext{
${ }^{6}$ Os originais dos manuscritos e sua sistematização por Carolyn Eisele nos foram apresentados, inicialmente (e informalmente), por Nathan Houser, em 1999, durante estágio de pós-doutoramento do primeiro autor, realizado junto à Indiana University. Um primeiro artigo sobre o assunto foi elaborado ainda naquele mesmo ano (GARNICA, 2001), paralelamente às atividades de pesquisa do projeto central, que tinha outro tema como foco. Foi apenas cerca de uma década depois que um projeto específico, envolvendo a tradução e a hermenêutica de textos, começou a ser desenvolvido. Daí a proposta de não apenas estudar a Aritmética Elementar de Peirce, mas, como já havia ocorrido com livros de Lewis Carroll (2015) e S-F. Lacroix (2013), traduzi-la e estudá-la, publicando integralmente a tradução.
} 
público mais amplo que aquele familiarizado com a Matemática formal, já que essa Aritmética, embora supostamente elementar, vem permeada de conceitos mais avançados. Algumas explicações, que anexamos em forma de notas de rodapé, estão relacionadas à explicação dos motivos que nos levaram a escolher, em alguns casos, entre uma determinada palavra ou outra, a explicações de fatos ou termos utilizados no texto por Peirce - como no caso das unidades de medidas metro e grama, usadas nos Manuscritos 168 e 167 - e às explanações históricas que elucidam termos e nomes próprios usados no texto pelo autor. Em momento algum, porém, alteramos propositalmente o sentido das frases, tentando significar ou explicar mais do que o autor pareceu, segundo nossa compreensão, ter pretendido.

Benjamin (2008) argumenta que a tradução é uma forma que, para ser compreendida, nos obriga a recorrer à obra original, pois nela reside a fórmula ou a lei de sua traduzibilidade - ou tradutibilidade. A tradutibilidade é o que há de essencial e que, por vezes, é esquecido pelos tradutores que se preocupam apenas com a transmissão dos conteúdos e com a forma da obra original, esquecendo-se de outros detalhes, também importantes, cuja transmissão tornase essencial.

Andrade e Garnica (2015) argumentam que as ideias originais estão, de algum modo, no texto original, e que o tradutor é um interlocutor que busca adaptar a obra à língua-meta. Eles compreendem que o texto não é constituído por um amontoado de palavras, pois ele tem um sentido original que é preciso, tanto quanto possível, preservar, buscando-se ser o mais fiel possível ao idioma de origem, evitando distanciar o sentido do texto original do texto traduzido. Para que isso aconteça, é fundamental que o tradutor esteja familiarizado com as línguas envolvidas, compreendendo termos e sentenças, transitando pelos usos que uma determinada comunidade faz de sua linguagem.

Para Eco (2014, p. 17 e 18):

[...] traduzir quer dizer entender o sistema interno de uma língua, a estrutura de um texto dado nessa língua e construir um duplo do sistema textual que, submetido a uma certa discrição, possa produzir efeitos análogos no leitor, tanto no plano semântico e sintático, quanto no plano estilístico, métrico, fonossimbólico, e quanto aos efeitos passionais para os quais tendia o texto fonte. 'Submetido a uma certa discrição' significa que toda tradução apresenta margens de infidelidade em relação a um núcleo de suposta fidelidade, mas que a decisão acerca da posição do núcleo e a amplitude das margens depende dos objetivos que o tradutor se coloca.

Podemos, então, perceber que Eco (2014) e Benjamin (2008), no que nos interessa, entendem de modo próximo a tradução, que, para eles, não é uma passagem de um texto de uma língua a outra, mas um processo de negociações e turbulências intimamente voltado aos objetivos do tradutor, que precisa estar atento às várias nuanças do texto traduzido. Assim, 
essa busca se transforma em tentar dizer quase a mesma coisa que o texto original, não se esquecendo que esse quase é elástico e está diretamente relacionado às várias negociações que o tradutor tem de fazer para manter-se o mais fiel possível ao texto fonte, atentando, inclusive, para a reversibilidade da tradução.

Para Campos (1986), não é suficiente ao tradutor possuir um vasto e amplo conhecimento na língua estrangeira, pois a tradução não é apenas a passagem de uma língua a outra, mas, também, a passagem de uma cultura a outra. Nesse sentido, é fundamental que o tradutor, para devidamente estar qualificado a proceder com a tradução, possua um grande repertório de conhecimentos e de cultura geral, de modo a preencher os requisitos para a tradução de um texto. É compreensível, assim, que a tarefa do tradutor seja cuidar para que esses conhecimentos se ampliem e se aperfeiçoem. Eco (2014, p. 190) adota um posicionamento similar, ao dizer

[...] que uma tradução não diz respeito apenas a uma passagem entre duas línguas, mas entre duas culturas, ou duas enciclopédias. Um tradutor não deve levar em conta somente as regras estritamente linguísticas, mas também os elementos culturais, no sentido mais amplo do termo.

Com isso, temos que a tradução não depende unicamente do contexto linguístico, mas, também, de algo que está fora do texto, o que Eco (2014, p. 322) chama de informações acerca do mundo ou informações enciclopédicas. Eco afirma, ainda, que "toda tradução (e por isso as traduções envelhecem) se move em um horizonte de tradições e convenções literárias que fatalmente influenciam as escolhas de gosto".

Para Benjamin (2008) é preciso estar alerta para a necessidade de considerar que a língua na qual a obra original foi escrita passou e passa por um processo de maturação, e termos que eram antes atuais, podem, hoje, não mais possuir o mesmo significado ou, ainda, terem caído em desuso. Nesse sentido, toda língua, inclusive a do tradutor, passa por esse processo de amadurecimento. Assim, como consequência, é impossível pensar em uma tradução final, pois com o amadurecimento das línguas a tradução torna-se ou pode tornar-se obsoleta.

Não raras vezes é preciso que o tradutor se posicione como negociador num debate em que nem sempre está previsto o assentimento explícito das partes, uma vez que o tradutor às vezes negocia com um autor já falecido ou com um editor não especializado. A questão central é em que medida e de quais coisas se pode abrir mão nesse processo em que se renuncia a alguma coisa para obter outra, de modo que, ao final, as partes experimentem uma sensação razoável de satisfação, já que não se pode ter tudo. O tradutor deve estar atento às 
várias nuanças presentes em um texto. Uma delas exige estar próximo ao significado explícito em termos de conteúdo, uma outra está relacionada às coisas que os autores disseram implicitamente, ou seja, nas entrelinhas, e, finalmente, deve-se cuidar da forma do texto, o que faz com que a tradução de poesia seja um desafio ainda maior que a tradução de prosa.

No caso da Aritmética Elementar, há exemplos que ilustram bem algumas dessas dificuldades. No Manuscrito 189, Peirce vale-se de uma rima com a intenção de ancorar o ensino de contagem até treze. Ele mobiliza brincadeiras conhecidas das crianças americanas algumas delas ainda familiares às crianças do presente, outras já ultrapassadas - para fazer as contagens que ele tinha em mente. As rimas não são conhecidas por nós, brasileiros, e a tradução palavra por palavra, ver-se-á, era impossível, mas a intenção de utilizar as rimas como recurso para a contagem ou uma primeira aproximação com os números, obviamente deveria ser mantida.

Tínhamos, então, duas opções: ou reescrevíamos as rimas, substituindo-as por outras, ou as mantínhamos como estavam, sem traduzi-las. Optamos por fazer uma reelaboração, que visou preservar a forma e o ritmo das frases, contribuindo para manter as intenções de Peirce, ainda que fugindo da literalidade, uma vez que nos afastamos do que o texto dizia em língua inglesa. Ao invés das rimas utilizadas por Peirce, escolhemos rimas conhecidas das crianças brasileiras $^{7}$ e que nos ajudaram a manter a intenção original, mantendo, inclusive, sem prejuízo o ritmo próprio da forma cantada da rima:

A rima original

${ }^{*}$ Eeny, ${ }^{-}$Meny, Méye

Tusca, Rora,

Cabell, Broke a well,

Wee, Woe, Whack!

Peek, Doorway, -Tries, What wore he,

Punchy, ${ }^{-}$Switches,

${ }^{*}$ Ash-pan, ${ }^{*}$ avy,

Dash them, Gravy,

Do you knock 'em, Down!

Foi, então, substituída por

"uni $\varpi^{-}$tuni,

salamêmin ${ }^{-}$guê,

"um sorvete colorê,

o escolhido foi vo cê!

Minha mãe mandou

\footnotetext{
${ }^{7}$ Sabendo, obviamente, que a tradução não seria utilizada em escolas de primeiras letras.
} 


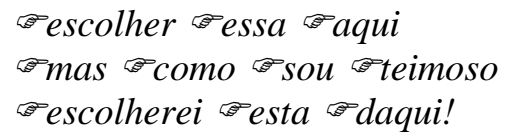

Não se trata, apenas, de usar algo do universo infantil como estratégia para o ensino de Matemática, mas de fundamentar todo o processo de ensino de contagem num processo de associação um a um, entre coisas e sons, coisas e números, números e sons. Há, também - e uma nota incluída por Eisele é essencial para compreendermos isso - um certo apelo a elementos culturais nesse modo de usar as rimas. Segundo Peirce, em carta de 1904 a W. Newell, as rimas americanas tinham, indefectivelmente, treze sílabas em seu total; doze sempre foi a quantidade de pessoas na composição dos júris populares; desde sempre a ideia de azar esteve atribuída ao número treze; e a depender das palavras usadas nas rimas, elas poderiam ser sóbrias, alegres, solenes ou trágicas. Desses ingredientes resulta que as rimas poderiam ter sido usadas para selecionar juris populares, e, ainda que essa fosse uma teoria sem comprovação alguma - segundo o próprio Peirce reconhece - é isso que ele ensina às crianças quando inicialmente apresenta, na Lição II do MS 189, números como palavras de contagem, vinculando essa apresentação às tradições ("Essa era a tradição. Você sabe o que é tradição? É qualquer coisa que as pessoas mais velhas seguem ensinando para as pessoas mais jovens por tanto tempo que até perdem a conta" (GARNICA; SOUZA, 2018)) ${ }^{8}$. Nossas rimas infantis mais conhecidas não têm, necessariamente, treze sílabas, como exige o texto original, daí a necessidade de, ao mobilizar as rimas brasileiras, dar a elas uma versão e um ritmo levemente alternativos.

Uma outra reelaboração que fizemos no texto de Peirce foi de natureza, digamos, mais estética, quando o autor lista uma sequência de objetos de contagem, ou objetos que podem ser contados e que, no original, eram palavras iniciadas pela letra B. Pareceu-nos mais adequado, em português, usar palavras iniciadas pela letra $\mathrm{C}$, em substituição. Assim, a sentença em inglês,

One of the things that we have to do very often is to find out how many things of the same kind there are in some box or bag, or basket or barrel or bank or basin or bucket, or bureau, or bottle, or bowl, or bunker, or bird's nest, or buffet, or boiler, or barrow, or barn-bay, or book, or be it what it may, or to find out how many times anything happens, or any other kind of how many.

tornou-se:

Algo que precisamos fazer com frequência é descobrir quantas coisas do mesmo tipo

\footnotetext{
${ }^{8}$ As citações textuais da Aritmética Elementar de Peirce são aquelas da tradução disponível integralmente em Garnica e Souza (2018). Sendo essa uma obra ainda no prelo, não segue indicada, nesse caso, e ao longo deste artigo, a paginação das citações dela extraídas.
} 
há em uma caixa, capela ou caixote, numa carroça, caldeira ou caldeirão, numa colmeia ou coleção, numa colcha, casa ou casebre, ou castelo, colchão ou candelabro, numa cesta ou cidade, num celeiro ou num circo, ou seja lá o que for, ou descobrir quantas vezes alguma coisa acontece, ou qualquer outro tipo de quantos.

Em termos de fidelidade, Benjamin (2008) entende que a tradução não pode ser assegurada pela tradução de cada palavra em separado, já que algo como um sentido poético é mais propriamente caracterizado por um agrupamento de palavras. Além disso, sabe-se de um consenso entre tradutores sobre o texto de caráter científico ter, por assim dizer, preferência pelo conteúdo em detrimento da forma.

\section{Os manuscritos da Aritmética Elementar: breves apresentação e considerações}

Segundo Eisele, o próprio Peirce afirma em uma de suas cartas que esses Manuscritos não tratam propriamente da Aritmética, mas do que poderíamos chamar Augrim ${ }^{9}$ que, para ele, significaria a arte de usar os algarismos arábicos. Peirce diz que, infelizmente, este termo caiu em desuso, e ele se vê em situação muito difícil ao tentar encontrar um termo substituto. O primeiro termo que lhe vem à mente para a substituição é Logística, a arte do cálculo em geral. A expressão Aritmética Vulgar é uma opção que ele julga incorreta e não convidativa. Também, a expressão Aritmética Prática é, segundo ele, ruim, e nenhum escritor que se preze a utilizaria (ainda que ele mesmo se contradiga e a use fartamente, principalmente nos Manuscritos 167 e 168).

Para Peirce, o interessante seria encontrar um título que estivesse de acordo com o velho e bom estilo elisabetano (PEIRCE, 1976), ainda que não se possa entender, pela falta de maiores detalhamentos, o que ele queria dizer com isso ${ }^{10}$. Continuando seu comentário, Peirce diz ter elaborado um plano para todo o trabalho, e apresenta, em síntese, o tema de cada volume por ele projetado para essa sua obra: (a) o primeiro deles teria como propósito tornar interessante o assunto para os pequeninos - e a avaliação de professores demonstrava,

\footnotetext{
${ }^{9} \mathrm{O}$ termo está relacionado às pedras usadas para contagem ou, ainda, à expressão numerais arábicos. São essas as poucas informações que obtivemos sobre isso. O único dicionário on-line em que pudemos encontrar Augrim como verbete é aquele disponibilizado em http://www.thinkenglish.me/definition/augrim.html.

${ }^{10} \mathrm{O}$ período Elizabetano (ou Isabelino), na Inglaterra, usualmente é caracterizado como de extrema bemaventurança graças ao governo de Elizabeth, filha de Henrique VIII, no auge do Renascimento inglês, quando a Itália, berço do Renascimento, padecia sob o domínio estrangeiro. Ainda que, atualmente, os historiadores tenham leituras alternativas dessa chamada Época de Ouro, questionando-se, por exemplo, sobre o bem-estar econômico e o poder militar ingleses, a cultura é um dos marcadores mais nítidos desse período e, nela, certamente, o desenvolvimento do teatro e das letras. Não se trata, porém - e aqui falam os críticos da atualidade -, de um teatro inédito, mas de uma realização altamente inspirada e muitíssimo bem desenvolvida que teve como referência os teatros grego e romano da Antiguidade. Na moda, a inspiração dos volumes horizontais e das altas golas vinha da Espanha e da França; na religião, ocorria o assentamento do Anglicanismo.
} 
segundo Peirce, o valor de seu método; (b) o segundo volume trataria do conceito de números inteiros e decimais que, em toda obra, seriam tidos como puramente ordinais, sem fazer referência a intervalos, ainda que ao mesmo tempo ele os relacionasse à questão Quantos são?, tratando, portanto, os números, do ponto de vista da contagem. Como se vê, uma das ideias de Peirce era, pelo menos em algum momento da elaboração desses originais, ter todos os textos dos Manuscritos, quando finalizados, publicados em dois volumes. Além disso, cabe ressaltar que, considerada a afirmação de Peirce - sempre questionável quando tratando em suas correspondências desses manuscritos ${ }^{11}$-, sua proposta, de algum modo, havia sido testada por professores, que aprovaram seu método ${ }^{12}$.

Algumas das referências de Peirce para a elaboração dos Manuscritos são apontadas por ele próprio ou por seus biógrafos. A influência do pai, Benjamin Peirce ${ }^{13}$, é clara já no início do texto Aritmética elementar de Peirce: sobre o método psicológico, que complementa o MS 179, quando o autor afirma:

\begin{abstract}
Meu pai, Professor Benjamin Peirce, um célebre matemático, de modo muito peculiar, ensinou-me aritmética segundo o mesmo método pelo qual ele, com muito sucesso, aprendeu essa arte, valendo-se dos melhoramentos que sua experiência lhe sugeriu. Os estudos de psicologia moderna permitiram que eu aperfeiçoasse ainda mais esse sistema, e após ter certeza das vantagens desse processo, eu, aqui, ofereço-o de uma forma prática aos professores de nossa comunidade.
\end{abstract}

Também Thomas Fiske ${ }^{14}$, de algum modo, pode ter levado Peirce a encarregar-se da tarefa de produzir manuscritos para o ensino de Aritmética Elementar. Por duas vezes, em 1894, Fiske, que então recentemente havia fundado a American Mathematical Society, convidou Peirce para publicar algo no The Bulletin of the New York Mathematical Society.

\footnotetext{
${ }^{11}$ Peirce obteve de seu editor um adiantamento para escrever uma série de manuais didáticos. Perdulário e desorganizado, Peirce atrasou e protelou tanto quanto pode a entrega dos materiais, até envolver-se judicialmente com a editora. Em cartas a amigos, familiares e empregadores, frequentemente mentia sobre o andamento do trabalho como que para justificar os atrasos, não perder a possibilidade de outros adiantamentos e/ou não precisar devolver os adiantamentos já recebidos.

${ }^{12}$ Nenhuma referência nos permite dizer que houve, efetivamente, alguma experiência prévia de Peirce com professores nesse sentido. Pelo contrário, sabe-se que a biografia de Peirce é tanto recheada de exemplos que atestam sua personalidade difícil e seus problemas de relacionamento pessoais e profissionais, quanto marcada por um distanciamento sensível em relação à realidade dos ensinos primário e secundário e mesmo do ensino superior. Tendo interesse em beneficiar-se da publicação desses manuscritos, não seria de todo estranho se essa afirmação sobre a aprovação prévia dos professores quanto aos seus métodos fosse mais um recurso enganoso de promoção das qualidades que ele, mais que ninguém, à época, parecia perceber em si mesmo.

${ }^{13}$ Benjamin Peirce graduou-se no Harvard College, em 1829, foi professor de Astronomia e Matemática na Harvard University, sendo considerado um dos mais conceituados matemáticos estadunidenses de sua geração. Foi presidente da American Associacion for the Advancement of Science, um dos fundadores da National Academy of Sciences, em 1863, e superintendente da United States Coast and Geodetic Survey, de 1867 até 1874 (PEIRCE, 1982).

14 Thomas Scott Fiske (1865-1944) foi professor da Columbia University e fundou a American Mathematical Society, em 1888, sendo seu presidente entre os anos de 1903 e 1904.
} 
Peirce era membro dessa Sociedade e isso pode tê-lo influenciado, ajudando-o a compor suas concepções acerca da educação e do ensino de Matemática (PEIRCE, 1976).

Segundo Eisele, com a vinculação à Sociedade veio a influência de Felix Klein quanto às diretrizes para os cursos de Matemática e ao ensino de Matemática nos Estados Unidos. Eisele conta que Peirce era um bom conhecedor da filosofia de Klein, e que existem evidências de Klein por todos os Manuscritos de Peirce (PEIRCE, 1976). Peirce também foi influenciado em sua filosofia matemática e educacional pelos muitos volumes do Bulletin, que tratavam das revoluções que, à época, ocorriam quanto ao que se entendia por ensinar Matemática. Segundo Eisele, Peirce tornou-se um especialista em trazer para o aluno, e para o público em geral, uma explicação da metodologia da matemática de seu tempo, ainda que tenha sofrido com o pouco reconhecimento de sua obra em vida.

Tanto quanto ocorreu no Brasil, onde a influência francesa nos livros didáticos escolares foi determinante para o padrão desses materiais e para a própria concepção de ensino e escola, o modelo francês era quase hegemônico na Educação americana nos tempos de Peirce, tendo Legendre ${ }^{15}$ sempre servido como parâmetro para os escritores, sendo que seus livros foram traduzidos para o inglês em 1819. O pai de Peirce também escreveu livros didáticos elementares - seu livro de Geometria, por exemplo, ultrapassou as fronteiras americanas e foi, inclusive, especificamente analisado por Lewis Carroll (2015) em sua crítica quanto à intenção inglesa de substituir o livro de Euclides como manual nas escolas da época: o livro de Geometria de Benjamin Peirce, para Carroll, é um dos rivais de Euclides em meados do século XIX ${ }^{16}$.

Os livros didáticos sobre Matemática Elementar, nos Estados Unidos, até os tempos em que Charles Sanders Peirce se envolveu com o assunto, refletiam pouco o que ocorria nesse momento do século XIX, quando o pensamento matemático e os modelos de ensino de Matemática passavam por alterações radicais, sendo objetos de inúmeras discussões e experiências.

No entanto, às portas do século XX, a necessidade de uma revisão curricular da Matemática escolar em todo o mundo tornou-se aparente, e medidas como a criação de uma comissão dirigida por Felix Klein foram, então, tomadas no Congresso Internacional de Matemática, em Roma, no ano de 1908, intensificando a implementação de novas ideias. Peirce, segundo Eisele, antecipou essa revisão na elaboração dos seus próprios livros

\footnotetext{
${ }^{15}$ Adrien-Marie Legendre, matemático francês, viveu entre 1752 e 1833.

${ }^{16}$ Euclides e seus Rivais Modernos, de 1879, foi publicado em português pela Livraria da Física, em 2015.
} 
didáticos. O desenvolvimento lógico do assunto, seu simbolismo, sua inventividade, as nomenclaturas cuidadosas - refletindo seu trabalho como linguista e dicionarista -, sua profunda apreciação da estrutura topológica nos níveis mais básicos de ensino ${ }^{17}$, sua fascinação em relação às geometrias não Euclidianas, tudo isso, de acordo com Eisele, marcam seus manuscritos de Matemática.

Resta-nos, aqui, portanto, apresentar, mais detalhadamente, cada um dos manuscritos de Aritmética Elementar, para que o leitor tenha outros elementos para concordar - ou não com essas afirmações sobre a criatividade desses livros nunca publicados.

\subsection{O Manuscrito 189}

O MS 189, que tem como título Aritmética Elementar de Lydia Peirce é composto por duas versões do que seria um mesmo texto: a primeira traz dois subitens chamados Lições, que se mantêm na segunda versão, ainda que esta seja maior e mais completa em comparação com a primeira. Há, entretanto, pálidas diferenças de intenção entre essas duas elaborações propostas por Peirce, e mais marcada fica a diferença de elaboração textual.

Um aviso inicial do autor indica que não é preciso que as crianças estejam alfabetizadas para usar o material, ainda que, alfabetizadas ou não, todas devam ter uma cópia em mãos. A primeira lição se inicia nos moldes das historietas infantis (Era uma vez, há muitos e muitos anos...) cujas personagens são Bárbara, Lydia e Benjamin (indicado por seus diminutivos Benjy, Benjie ou Ben), com uma rapidíssima aparição de um Tio Charles. Lydia, Benjamin e Charles são nomes próprios da família de Peirce, enquanto Barbara talvez seja uma referência ao conhecido silogismo. Cartas ou cartões numerados, que devem ser mostrados em sincronia com objetos apresentados pelo professor, são os materiais básicos para toda a lição e, mais, são recursos presentes em todos os manuscritos que compõem a Aritmética Elementar.

A primeira lição é curta, trazendo apenas uma apresentação das personagens que será melhor desenvolvida na segunda versão do manuscrito. Já de início percebe-se, também, o recurso às rimas infantis que foi mobilizado em vários outros momentos, ao longo dos manuscritos. Números, cartões numerados, sílabas, rimas, frases ritmadas são recursos de

\footnotetext{
17 É importante notar que esse ramo da Matemática apenas começou a ser desenvolvido com Brouwer (18811966), que concluiu a parte mais importante de seu trabalho em Topologia entre os anos de 1909 e 1913. Também o Movimento Matemática Moderna, posteriormente, apostará nas estruturas topológicas para alterar o panorama do ensino de Matemática (SILVA; VALENTE, 2014).
} 
contagem ou, segundo Peirce, são (ou operam como) palavras de contagem.

A segunda versão do manuscrito é quatro vezes maior que a primeira. Mais detalhada, traz exemplos e subtópicos. A primeira lição, nessa segunda versão, inicia-se com historieta de mesma natureza da já apresentada na primeira versão, mas há, nela, elementos inusitados para uma casa que se situa na floresta: há, por exemplo, um poço de gás natural e um sistema de tubos que abastece a casa com aquecimento e eletricidade. Há destaque para uma roda d’água e suas funções. Esses elementos são tributários do interesse e do envolvimento de Peirce com estudos relacionados às modernas tecnologias existentes à época, em boa parte relativos aos trabalhos que, além de apreciar, ele sistematicamente ou desenvolvia ou conhecia o desenvolvimento dado o contato próximo com pesquisadores e instituições voltadas a pesquisas dessa natureza como, por exemplo, a United States Coast and Geodetic Survey ${ }^{18}$, onde Peirce trabalhou por muito tempo, seguindo uma tradição familiar, já que seu pai também havia sido um influente membro dessa instituição.

Jogos de codificação e sistemas de localização fazem parte das aulas que Lydia dá às crianças (Barbara e Benjie). Tais jogos estão, no início dessa versão do manuscrito, ligados à relação biunívoca entre as coisas e as sílabas ritmadas das rimas infantis, assim como ocorria - ainda que com menor ênfase - na primeira versão do manuscrito. Tanto quanto na primeira versão, porém, a Lição I é brevíssima e a historieta que abre a Lição II muito rapidamente cede lugar ao tópico Multiplicação, cujo desenvolvimento, ainda que se apresente na forma de diálogos entre Lydia e as crianças, despreza flagrantemente as historietas e rimas e impõe um movimento, digamos, mais clássico, mais sisudo, mais técnico, próprio das aulas de matemática usuais e tradicionais. Recitada a tabuada ( 0 vez 1 é zero; 1 vez 2 é 2 ; duas vezes 3 é 6 etc), a multiplicação é feita usando o processo dos quartos de quadrado que, sabemos, é atribuído aos babilônicos. Ainda que nada seja comentado sobre isso, a técnica consiste em multiplicar $\mathrm{x}$ por $\mathrm{y}$ usando os quartos de quadrado de $\mathrm{x}+\mathrm{y}$ e $\mathrm{x}-\mathrm{y}$, aplicando a igualdade $x \cdot y=\frac{(x+y)^{2}}{4}-\frac{(x-y)^{2}}{4}$.

É importante reiterar, nessa análise do manuscrito, que nada acerca disso (o que é um quarto de quadrado, quais suas origens, porque a multiplicação pode ser feita a partir dos

18 A criação da Coast and Geodetic Survey ocorreu em 1807, no governo de Thomas Jefferson, sob a superintendência do matemático suíço Ferdinand Rudolph Hassler (1770-1843). Devido a algumas tensões entre civis e militares, a agência foi fechada pelo Congresso até o ano de 1832, quando foi reaberta, sob o comando da Marinha, como uma agência civil. Desde então, seu principal objetivo foi produzir informações náuticas, mas acabou, também, atuando em questões de fronteira, comércio e defesa. Essa agência americana de estudos e pesquisa guarda, em muito, similaridades com o Bureau de Longitudes francês. 
quartos de quadrado, como se dá a multiplicação por esse método etc.) é discutido no manuscrito, do que talvez se possa afirmar ou que a técnica era bem conhecida e bastante usada ou que em revisões posteriores do manuscrito (que, aparentemente, não chegaram a ser feitas pelo autor) essa lacuna seria notada e preenchida. No texto indica-se, apenas: "Lembrem agora do quarto do quadrado: o quarto do quadrado de 0 é 0 vez 0 , ou 0 / O quarto do quadrado de 1 é 0 vez 1 , ou 0 / ... O quarto do quadrado de 17 é 8 vezes 9, ou 72 / O quarto do quadrado de 18 é 9 vezes 9, ou 81" (GARNICA; SOUZA, 2018).

A única discussão ocorre pela exemplificação, ainda que, segundo nosso ponto de vista, essa exemplificação seja inadequada, já que é extremamente cifrada e implica conhecimentos matemáticos, ou pré-requisitos, consideráveis. Só depois de apresentar, em dezoito linhas consecutivas os quartos de quadrado de 1 a 18, como referenciado acima, o autor afirma: "Se você procura o produto de 6 e 7, você deve adicionar os fatores, que dá 13, e subtrair o menor do maior, que dá 1. Então você subtrai o quarto do quadrado de 1, ou zero, do quarto do quadrado de 13, ou 42, e este será o produto", (GARNICA; SOUZA, 2018) o que nos parece bastante insuficiente, já que além desse há apenas mais dois exemplos (para $7 \times 9$ e 3x8) com a mesma redação.

Pode-se aventar, portanto, que Peirce tinha em mente públicos distintos ao escrever sua Aritmética Elementar: ora ele dialogava com crianças, ora se esquecia totalmente delas e se embrenhava em cálculos e apresentações estéreis e impróprias a elas, pressupondo um leitor mais especializado que aqueles em fase de alfabetização matemática aos quais, em princípio, a obra se dirigiria. Pode-se aventar, também, que essas estratégias mobilizadas por Peirce estavam plasmadas num completo desconhecimento da perspectiva da criança - ainda que ele afirme que seu texto foi elaborado a partir do estudo das teorias mais atualizadas em Psicologia e Pedagogia - e de seus modos de aprender, já que a familiaridade do autor com escolas reais de primeiras letras era inexistente, ele mesmo tendo sido, quando criança, educado em casa, pelo pai ${ }^{19}$.

A descrição de algoritmos sem justificativa alguma é uma constante em todos os manuscritos. Tratando-se, entretanto, de manuscritos, não se pode afirmar se essas justificativas seriam ou não incluídas posteriormente, quando da redação final do texto. Os problemas financeiros que acompanharam Peirce por toda sua vida adulta, aliados à sua

\footnotetext{
${ }^{19}$ Segundo Eisele (1959) e Brent (1998), o pai de Peirce cultivou pessoalmente os talentos do filho. Segundo os biógrafos, Benjamin Peirce encontrou nos filhos o talento que não encontrava em seus alunos, de modo que Peirce foi, dentre os demais filhos, o que mais sofreu a influência do pai.
} 
arrogância acadêmica e à sua noção bastante flexível quanto aos modos de equilibrar suas contas, entretanto, nos permitem considerar que a elaboração desses manuscritos pode ter sido apressada, irresponsável e apoucada, meramente para dar conta de que um trabalho estava sendo realizado, de modo que os editores pudessem pagá-lo apenas pela perspectiva de ver, um dia, a obra publicada. Nem a obra foi publicada nem, como se sabe, essa estratégia de protelar a entrega das versões finais deu os resultados esperados, já que a uma certa altura o contrato com a editora foi rompido e os pagamentos cessados.

Ainda no tópico relativo à multiplicação, o autor trata, também, do chamado processo longo e seu algoritmo. Tenta-se, é verdade, justificar esse algoritmo num diálogo entre Lydia e Benjie, mas também essa justificativa não nos parece nem adequada, nem suficiente. Entretanto, o que poderia ser convincente numa Aritmética que trata da multiplicação sem que nada, antes, tenha sido dito acerca da adição, por exemplo? Fica óbvia, assim, uma vez mais, a lacunaridade dos manuscritos, e como Peirce, aparentemente, anotava ideias conforme lhe ocorriam, para, depois, dar-lhes uma estrutura mais definitiva e bem amarrada.

Tendo sido vitimados por inúmeras idas e vindas, guardados com pouco cuidado e esfacelados de várias maneiras, o que certamente implicou o desaparecimento de várias de suas partes, os manuscritos são de análise muito difícil, do que se pode, apenas, aventar possibilidades como as que temos registrado até agora. Cabe, ainda, em relação a essa discussão, questionar o que poderia ter levado Eisele a apresentar os manuscritos segundo essa ordenação por ela proposta, que aqui reproduzimos ${ }^{20}$.

À multiplicação segue o tópico relativo à divisão. O recurso aos cartões é o mote desse tópico. As atividades propostas usualmente sugerem que os cartões sejam distribuídos entre as crianças que, com eles, devem formar grupos de cartões. Tanto quanto nas demais partes desse manuscrito 189, a linguagem não é rebuscada: é usual, cotidiana. Além dos cartões, segue uma série de problemas que consistem em dividir as horas do dia, do que surge a apresentação de terminologia específica (terço, quinto, inteiro, quarto, divisão, quociente) e suas respectivas notações em linguagem matemática, bem como o algoritmo usado, à época, para o que Peirce chama de divisão curta. O tópico é interrompido para tratar do assunto Médias, o que se inicia com uma discussão - brevíssima - dos calendários Juliano e

\footnotetext{
${ }^{20}$ É importante notar que manuscritos posteriores, nessa série de manuscritos, tratarão de temas que, por sua vez, são anteriores aos temas tratados nesse manuscrito 189 (a adição, por exemplo). A própria numeração dos manuscritos é contrária à sequência de apresentação que Eisele usou para compor o The New Elements of Mathematics by Charles S. Peirce. Não há, entretanto, nenhuma consideração sua quanto à ordenação por ela imposta a esses textos.
} 
Gregoriano. Retoma-se o assunto das divisões para apresentar o que Peirce chama de divisão longa, a partir do problema que pergunta quantos meses equivalem a 365,2424 dias ${ }^{21}$.

Em alguns poucos excertos do manuscrito, Peirce tenta estabelecer metáforas ou explicações mais plausíveis para crianças: “Adição e multiplicação, ambas, fazem os números maiores /.../ se estivermos falando de números inteiros positivos /.../ a adição aumenta um número somando alguma coisa a ele, a multiplicação aumenta um número aumentando cada parte dele igualmente". Essa, por exemplo, é a síntese que abre a discussão sobre a Regra de Três, que, entretanto, será breve, tratada a partir de uma atividade com um elástico que retomará, também muito resumidamente, elementos dos tópicos Divisão e Multiplicação tratados anteriormente.

O próximo e último tópico do manuscrito, nessa segunda versão, é chamado de Problemas com cartões, um título dado por Eisele. Aqui aparecem, além de outros personagens que dialogam com Lydia, pela primeira vez, de modo sistemático, os cartões numerados de 1 a 101 que Peirce usará enfaticamente como recurso didático ao longo dos seus manuscritos.

Trata-se de uma série de cartões numerados sequencialmente, que caberia ao professor e aos alunos manipularem à exaustão já que, segundo Peirce, o aprendizado que decorrerá do uso desses cartões exige tanto a exatidão quanto a agilidade de manipulação. Assim, não se trata, apenas, de formar grupos, mas de formá-los rapidamente e, também rapidamente, responder a questões sobre os grupos formados. Os cartões devem ser dispostos, recolhidos, lidos, novamente amontoados e distribuídos segundo o mais rígido controle de quem os manipula. É preciso dominar a formação de padrões quando os 102 cartões são distribuídos em três grupos, quatro grupos, cinco, seis, sete... até dez grupos. Por exemplo, quando distribuídos sequencialmente em três grupos, no primeiro grupo estarão os cartões

$\begin{array}{cccccccccc}13 & 16 & 19 & 22 & 25 & 28 & 31 & 34 & 37 & 40 \\ 43 & 46 & 49 & 52 & 55 & 58 & 61 & 64 & 67 & 70 \\ 73 & 76 & 79 & 81 & 85 & 88 & 91 & 94 & 97 & 100\end{array}$

No terceiro grupo estarão os cartões

21 365,2424 é o número médio de dias no ano, em um calendário Gregoriano. 


$\begin{array}{cccccccccc}3 & 6 & 9 & 12 & 15 & 18 & 21 & 24 & 27 & 30 \\ 33 & 36 & 39 & 42 & 45 & 48 & 51 & 54 & 57 & 60 \\ 63 & 66 & 69 & 72 & 75 & 78 & 81 & 84 & 87 & 90 \\ 93 & 96 & 99 & & & & & & & \end{array}$

E as perguntas que seguem, ancoradas na divisão desses cartões em grupos, são, por exemplo: como terminam os números dos cartões do terceiro grupo quando os cartões estão divididos em cinco grupos? Quando estamos com cartões distribuídos em dois grupos, quais os valores dos cartões cujas posições terminam em um ou seis? Quais cartões ocupam a segunda, a sétima, a décima segunda e a décima sétima posições quando os cartões estão distribuídos em cinco grupos? Etc.

Distribuindo exaustivamente cartões em agrupamentos distintos, e elaborando uma série de perguntas sobre a composição desses agrupamentos, termina o MS 189.

\subsection{Os Manuscritos 181 e 182}

Dois pequenos textos compõem esse bloco, na edição organizada por Eisele. Eles vêm nomeados como Aritmética Elementar [com sugestões para professores]. Não há indicativo de onde termina um dos manuscritos e onde começa o outro. Há neles, ao todo, seis lições, sendo a última delas bastante mais extensa que as demais (ela ocupa treze das vinte e uma páginas do texto). A ênfase, já anunciada na breve introdução de três parágrafos, é que a ideia de número deve ser ensinada às crianças com o uso de imagens e diagramas simples, associando, sempre, algarismos a coisas. As coisas devem ser, sempre, mostradas, exibidas, nunca apenas supostas, e os cartões, mais uma vez, sejam aqueles numerados ou não, desempenham papel fundamental como objeto de ensino.

Não se pode compreender a razão que leva Peirce a interromper uma lição e iniciar outra e bem provavelmente essas interrupções tenham ocorrido devido a circunstâncias variadas, até mesmo comezinhas. Posto que são manuscritos, bem provavelmente na revisão final seriam incorporados outros exercícios, feitas complementações e exclusões, pois não há lógica subjacente que justifique o vínculo entre as lições. Devemos lembrar que os manuscritos, no processo de elaboração, contaram com um único revisor (informal), Edward 
Holden $^{22}$ (1846-1914), astrônomo, colega de Peirce.

A voz que canta os números e os associa às figuras, ao ponto, ao cartão, e dita o ritmo, é um elemento que complementa a associação entre algarismo e coisa. Trata-se, portanto, de uma tríade: algarismo-objeto-ritmo. A contagem é feita em ordem crescente e decrescente, de um em um, e são inúmeras as questões às quais as crianças devem responder usando os números que elas recitam de frente para trás e de trás para frente, várias vezes, muitas vezes. A repetição exaustiva é uma marca constante desse - e também de outros - manuscrito.

A Lição II explora a contagem até 3, a Lição IV explora a contagem até 6, a Lição V, a contagem até 7, a Lição VI até 8. Nas Lições tudo é feito da mesma forma, tudo é repetitivo. Termos como contar, crescente, decrescente, repetir são intensamente usados. Trata-se de praticar a contagem usando a relação entre algarismos e objetos, acrescentando ou reduzindo os objetos a serem contados. Na Lição VI esse compasso se altera um pouco, com a proposta de uma atividade que mobiliza bolinhas de gude, sacos brancos (nos quais devem caber dez bolinhas de gude) e sacos verdes (nos quais serão guardadas cem bolinhas de gude). As indicações são precisas: indica-se a construção de um ábaco que deve ter sete fios com contas em cores distintas (cobre, branca ou prateada, verde - o verde da nota de um dólar -, dourada ou amarela, azul claro, cinza, vermelho brilhante). Não se sabe, entretanto, por que indicações tão precisas foram feitas, além, é claro, de terem a função de diferenciar contas e sacos que, por sua vez, indicarão unidades, dezenas etc. A atividade consiste em contar as bolinhas de gude e juntá-las nos sacos pequenos até contar dez; fechá-lo, mover uma conta no ábaco a cada bola de gude ensacada, e uma conta branca/prateada a cada saco fechado, sempre dizendo em voz alta os números de um a dez. Fechados dez sacos brancos, todos vão para um saco verde e move-se no ábaco uma conta verde... dez sacos verdes devem caber em um saco amarelo etc.

Entende-se que Peirce propõe um exercício de contagem de dez em dez. O processo é tão simples quanto, hoje, usual no início da escolaridade. A tradução, ao contrário, traz uma dificuldade sensível. Como se verá no texto, dois dez, por exemplo, só posteriormente, num

\footnotetext{
${ }^{22}$ Sabe-se que, recém iniciado o século XX, Peirce troca correspondências com Edward S. Holden. Segundo os biógrafos de Peirce, Holden passa a ser um apoio para a elaboração da Aritmética. Em carta de janeiro de 1901, Holden informa a Peirce ter lido os Manuscritos sobre a Aritmética, e complementa informando ter sido um grande prazer intelectual encontrar neles boas ideias. Após esse elogio, seguem alguns apontamentos de Holden: (a) os Manuscritos da Aritmética Elementar têm, então, 31 páginas e estão bem completos até a parte em que se inicia a teoria acerca da contagem de oito-em-oito; (b) páginas variadas da Aritmética Elementar, talvez 100 delas - até os tópicos Multiplicação e Divisão - devem sofrer alterações; (c) o texto relativo à Aritmética Prática possui aproximadamente 15 páginas datilografadas e (d) as páginas com variadas anotações parecem úteis, segundo o ponto de vista de Holden. Segundo Holden, quase toda a Aritmética Prática estava ainda por ser escrita, e a Aritmética Elementar, àquela altura, estava pronta até quase a metade (PEIRCE, 1976).
} 
segundo momento, passará a ser vinte e, posteriormente ainda, duas dezenas. Assim, Ten Tens Ten (como Peirce usa, querendo significar Ten Tens and Ten), é cento e dez (antes de ser dez dezenas mais dez ou dez dezenas mais uma dezena ou mesmo onze dezenas), e Ten Ten Tens é mil. Dado que em português dez não tem plural (ao passo que tens, em inglês, significa tanto esse plural quanto dezena), ambos, 110 e 1000, traduzidos rigidamente, resultariam na mesma expressão (Dez Dez Dez). Isso implicou a necessidade de incluir, em português, conjunções que não aparecem no original. $\mathrm{O}$ uso do termo dezena, entretanto, não será explorado por Peirce nesse manuscrito. Curiosamente, ele inicia com a contagem de dez em dez, atribui os nomes específicos a alguns grupos de dez, mas, em seguida, inicia a exploração das contagens de dois em dois, de três em três etc. apenas até a contagem de seis em seis.

A contagem com as bolinhas de gude deve ser explorada exaustivamente, segundo indicação precisa do próprio autor. Ela deve induzir a uma familiaridade com os números. Praticada a contagem assim, Peirce retoma a mesma atividade, agora usando grãos de café e não mais bolinhas de gude. Contar exige atenção. O objetivo é contar corretamente, mas é também preciso contar rápido. Dos alunos que não cometerem erros, o mais rápido deve ser premiado. Por vários dias essas atividades devem ser repetidas.

A libra e a onça, unidades de massa, são mobilizadas por Peirce (uma libra, ele nos alerta, tem aproximadamente 2500 grãos verdes de café, enquanto uma onça tem de 155 a 160 grãos. A contagem deve seguir até serem usados 2500 grãos de café). Mais uma vez, fica patente o aproveitamento que Peirce faz dos temas que explora em suas atividades profissionais, em especial na Coast and Geodetic Survey.

Seguem-se a essas atividades exercícios complementares que implicam a contagem de 2 em 2, de 3 em 3, de 4 em 4, de 5 em 5 , de 6 em 6 e de 7 em 7, mesclados a problemas de aritmética simples (por exemplo: "Uma garotinha encontrou dois alfinetes no domingo, mais dois na segunda-feira: quantos alfinetes ela encontrou? Ela encontrou mais dois na terça-feira: quantos ela tem agora? Mais dois na quarta-feira. Quantos? Mais dois na quinta-feira. Quantos? Quatorze em uma semana. Ela teve a mesma sorte na semana seguinte. Quantos no domingo? Segunda? Terça? Quarta? Quinta? Sexta? Sábado?” (GARNICA; SOUZA, 2018). Volta-se a usar os cartões numerados de 1 a 101 para que os alunos formem grupos de cartões, percebam a formação de sequências, atentem para a ordenação dos números. Esse método, segundo o próprio Peirce, é penoso, mas necessário e indispensável. Para efetivá-lo pode-se usar o tempo que for, contanto que as crianças não fiquem fatigadas ou indispostas. 


\title{
3.3 O Manuscrito 179
}

O MS 179 - Aritmética Elementar de Peirce: sobre o método psicológico - inicia-se com um tom biográfico: o autor refere-se ao modo como ele próprio foi educado por seu pai, Benjamin. Não há, propriamente, um vínculo entre o texto do manuscrito e o título proposto por Eisele. O que deveria ser - a julgar pelo título - uma discussão acerca dos fundamentos sobre os processos psicológicos relacionados ao ensino e à aprendizagem da Aritmética Elementar, acaba por ser um conjunto de historietas em que se encontram situações-problema para o ensino de operações e conceitos. Assim, o manuscrito trata da ação de medir quando se precisa comprar certa quantidade de tecido sem ter à mão um padrão de referência ou, num tom mais dramático, de, durante um passeio no parque, juntar centavos para comprar sapatos para uma menina pobre.

As personagens são a senhorita Sessions e as crianças que frequentam sua escola (ou seus pequenos jardins, como ela as chama). Quando graduando em Harvard, Peirce registrou num texto intitulado My Life Written for the Class Book, no ano de 1859, uma breve sequência de informações biográficas correspondentes ao período de 1839 a 1859 . Na entrada relativa ao ano de 1846, ele afirma ter parado de frequentar a escola de Miss Sessions e começado a frequentar a escola de Miss Wares. Assim, o nome utilizado nesse manuscrito traz essa referência autobiográfica.

O detalhamento de Peirce para ensinar a somar é nada menos que espantoso. Vale a pena citar a explicação dada para que sejam somados os números relativos aos centavos que cada criança dará para comprar o sapato para a menina carente:

\begin{abstract}
Aponte, com um lápis, para cada número, justamente quando você estiver quase para somá-lo. O lápis não pode esconder o que vem depois. Comece de baixo. Diga 7 e, apontando para o 4, diga 11. Mas não diga isso em voz alta, mantenha-se calado. Então movimente o lápis para cima, de modo a apontar para o 4 acima. Não diga "Mais 4", nem para você mesmo. Mas olhe para o 4 e diga, para você mesmo, 15, mantendo seus lábios firmemente fechados. Se você parar para falar você não consegue adicionar rapidamente. Movimente seu lápis para cima, para o 3, e diga, para você mesmo: 21. Movimente o seu lápis acima, para o 8 , e diga para você mesmo: 29. Movimente o seu lápis acima, para o 5, e diga para você mesmo: 34 . Movimente o seu lápis acima para o 6, e diga para você mesmo: 40. Movimente o seu lápis acima, para o 9, e diga para você mesmo: 49. Movimente o lápis acima, para o 2, e diga para você mesmo: 51. Movimente o seu lápis acima, para o 11, e diga para você mesmo: 69. Desenhe uma linha abaixo da coluna de números e, abaixo dela, escreva 69. Esse é o valor total (GARNICA; SOUZA, 2018).
\end{abstract}

A soma de dezenas será melhor abordada com o exercício de contar as sílabas da estrofe de um hino religioso. Da adição de dezenas segue a subtração. Efetuar $26+25+24+$ $25+27+22$ leva a efetuar a subtração 365 - 31, do que segue a subtração 62622250 - 
32067880. Ou seja, é totalmente caótica a gradação das dificuldades impostas às crianças. Mais uma vez, como já se pôde notar nos manuscritos anteriores, explica-se minuciosamente como fazer, sem que nada seja dito sobre por que se faz o que se faz.

A multiplicação, ao contrário das operações anteriores - que ocorrem a partir de situações-problema que vão se colocando no texto, sem haver tópicos específicos - vem em um subtítulo próprio, que encerra o manuscrito. Nesse tópico, Peirce reforça a necessidade de se enfatizar a agilidade, a contagem de cor. Não é suficiente saber a tabuada e contar de 6 em 6, ou de 7 em 7 para saber quanto é o produto de 6 e 7: é preciso, de estalo, saber que 6 vezes 7 é 42 . O dispositivo que Peirce oferece para ensinar/aprender a multiplicar de cor é uma cruz, inspirada nos calendários circulares de manuscritos medievais, feita em papel e presa à página, pelo centro, por um fio. O uso dessa cruz faz surgir os conceitos de múltiplo, de diagonal, de direita, de paridade, e resultados como múltiplos de pares são pares. Mais uma vez, recorre-se aos cartões numerados de 1 a $101^{23}$.

Uma nota de rodapé, especificamente, incorporada ao manuscrito por Eisele, é importante para uma análise do texto. Trata-se de observações que Peirce faz a si mesmo, como lembretes:

Uma criança já praticou adição em grupos, e sabe desenvolvê-la com perfeição. Nada falta além de habituá-la a adicionar primeiramente um número e depois o outro, juntamente com a palavra. Exemplo introdutório. Pobre família sem comida. Cada membro contribuiu com alguma coisa. Enumere-as e as adicione. Encontre a soma total. Descreva o processo cuidadosamente. Uma família caminhando encontra uma garotinha sem sapatos (GARNICA; SOUZA, 2018).

Nota-se que o teor dramático não se reduziria apenas ao exemplo da menina descalça. Outra nota diz respeito às obras que Peirce anuncia ter consultado para elaborar seu manuscrito, que deveria ultrapassar em qualidade os textos disponíveis, à época, sobre o tema Aritmética Elementar:

A Aritmética Elementar de Sheldon começa assim: ele estabelece $1+1=2$ logo de início! Antes de introduzir o número 4! Isso é loucura! A Aritmética Básica de Wentworth introduz a coisa, mas não o nome da coisa, antes de usar todos os números. Ele, muito imprudentemente, descreve a importância do nome das coisas. O Primeiras Lições de Greenleaf, em Aritmética, faz o mesmo. O Primeiras Lições em Aritmética de Rickoff faz o mesmo. O Franklin faz o mesmo. O Novo Básico de Ray evita este grande erro. $O$ Novo Básico de Robinson evita-o parcialmente. $O$ Básico Progressivo de Robinson evita-o completamente (GARNICA; SOUZA, 2018).

Há, ainda, lembretes quanto à terminologia e conceitos a serem abordados nos textos: “Terminologia da adição: Adição, Adicione, junte, some; Valor total; 'Vai um'. Subtração:

\footnotetext{
${ }^{23}$ Em alguns momentos, Peirce fala de cartões numerados de 1 a 100.
} 
Subtraia, deduza, devolva; Minuendo; Subtraendo; Restante; Resto; emprestar" (GARNICA; SOUZA, 2018). Algumas dessas terminologias - mas não todas - são abordadas nesse e em outros manuscritos, mas não se pode falar que, em qualquer dos casos, essa abordagem esteja completa ou seja definitiva.

\subsection{O Manuscrito 178}

Embora o bloco incluído por Eisele no The New Elements of Mathematics by Charles S. Peirce indique apenas o MS 178, junto a esse manuscrito encontra-se, também, o MS 179. Ambos se confundem e foi opção de Eisele trazê-los juntos. O MS 177, chamado Prática da Aritmética Elementar, tem suas duas partes incluídas no MS 178 (Aritmética Elementar de C. S. Peirce: suas principais características). Ele se inicia com a discussão sobre numeração e sobre o modo de escrever os algoritmos para logo apresentar a adição como a parte mais indispensável da Matemática, querendo significar com Matemática, aqui, o universo da Aritmética.

Mais uma vez, os cartões numerados desempenham papel fundamental. Eles são distribuídos em ordem decrescente e usados para jogos em que adições são propostas. À subtração, tida como um pouco menos fácil que a adição, reserva-se apenas um parágrafo de duas linhas, afirmando que exercícios de subtrair serão úteis para aliviar dificuldades quando fazendo a divisão pelo processo longo. À essa nota breve sobre a subtração, segue-se a discussão sobre a multiplicação. Pretende-se, com ênfase, estimular a observação sobre leis de formação - como, por exemplo, perceber que nenhum produto na tabuada termina em 1 exceto uma vez em cada linha ímpar, excluída a quinta linha.

Essas leis de formação podem ser acompanhadas num quadro a ser construído em sala de aula ou num dispositivo, um material didático, cujo modelo Peirce disponibiliza para ser reproduzido em cartão pelos alunos ou pelo professor. Ainda que o texto não traga nenhuma fundamentação para as estratégias utilizadas (o que, aliás, caracteriza todos os manuscritos), aqui o autor indica que uma objeção quanto a usar dispositivos/materiais didáticos poderia ser a de que "os professores não entenderiam o princípio matemático no qual a estratégia se fundamenta, e [eles] poderiam, dessa forma, ficar expostos a questionamentos embaraçosos" (GARNICA; SOUZA, 2018). Nada mais, porém, é dito sobre isso.

Quando, mais uma vez, como já feito no MS 189, Peirce vale-se dos quartos de quadrados para operar multiplicativamente, uma explicação é dada: ele afirma que uma 
pequena brochura estará encartada à obra de Aritmética Superior, servindo tanto como livro de exercícios quanto como livro-texto, do que se depreende que, no livro avançado - que nunca foi elaborado ou encontrado - Peirce pretendia fundamentar conceitos e operacionalizações do ponto de vista matemático, o que a tornaria, portanto, uma obra mais diretamente voltada aos professores ou a um público especializado.

De resto, o manuscrito detém-se a explicar (melhor seria dizer apresentar), passo a passo, o algoritmo da multiplicação pelo processo longo, usando como exemplo o produto 87183 x 366917. A grande Aritmética - como Peirce também se refere à Aritmética Avançada - deveria tratar da multiplicação com o uso das Tábuas de Cálculo de Crelle ${ }^{24}$. Os logaritmos, ele afirma, serão trabalhados mais tarde. Ainda que nada sobre isso seja encontrado no manuscrito, fica registrado o tratamento aritmético do logaritmo, que será alterado apenas em meados do século XX, quando a opção passa a ser trabalhar a partir de um ponto de vista funcional, não mais decorrência das progressões, mas como parte do ensino de funções.

A divisão é o início natural de uma aritmética avançada, segundo o manual de Peirce. O tratamento que ele reserva a esse tópico, entretanto, aqui, nesse manuscrito, é, no mínimo, curioso. Ele afirma:

[...] para o aluno mais avançado será apropriado inserir aqui algumas lições complementares sobre este assunto. Mas na organização do livro será melhor alocar toda a parte teórica num mesmo momento, e seguir adiante com a Aritmética Elementar usando proposições da aritmética superior que poderão ser mobilizadas sem provas ou explicações (GARNICA; SOUZA, 2018).

Com isso, ele parece eximir-se de justificar, na Aritmética Elementar, qualquer asserção, algoritmo ou técnica para além da descrição de sua efetivação, de sua aplicação prática. Um exemplo de por que essa abordagem é, no mínimo, estranha, está na sentença: "Deve-se afirmar que a quantidade de algarismos numa dízima periódica, representada por uma fração, é igual ao totiente ${ }^{25}$ do denominador, isto é, igual à quantidade de números menores ou iguais ao denominador, co-primos a ele" (GARNICA; SOUZA, 2018).

A julgar pela deficitária rede de formação de professores nos Estados Unidos à época, é de se supor que, com ou sem o apoio de uma Aritmética Avançada na qual esses conceitos

\footnotetext{
${ }^{24}$ August Leopold Crelle (1780-1855) foi um matemático e engenheiro alemão, muito conhecido na História da Matemática por haver fundado, em 1826, o Journal für die reine und angewandte Mathematik. As Rechentafeln (tábuas de cálculo, ou tabelas de cálculo) de Crelle foram publicadas em 1820.

${ }^{25}$ A referência de Peirce, aqui, trata da chamada função totiente de Euler. O totiente de um número natural k é a quantidade de números menores ou iguais a k, coprimos em relação a ele. Em linguagem matemática, o totiente é definido como a função $\varphi(k)=o(A)$ onde $\mathrm{o}(A)$ é a ordem do conjunto $\mathrm{A}=\{n \in N ; n \leq k \wedge \operatorname{mdc}(n, k)=1\}$.
} 
seriam apresentados e discutidos, essa sentença é, no mínimo, demasiadamente sofisticada do ponto de vista matemático. Mas dessa afirmação segue uma discussão sobre o estudo dos restos em que são simplesmente enunciadas as regras relativas ao resto das divisões por 2, 3, $4,5,7,8,9,10,11,12,13,17,19$ e 23, em parágrafos que soam como requintes de perversão, a julgar pela formação dos professores primários do final do século XIX, nos Estados Unidos (SOUZA; GARNICA; SALANDIM, 2018). Senão, vejamos, por exemplo, dois desses enunciados, relativos, respectivamente, ao resto da divisão por 6 e por 7 :

O resto da divisão por 6 é o mesmo resto da divisão do último algarismo diminuído do dobro da soma do resto dos algarismos.

O resto da divisão por 7 é o mesmo resto deixado pela divisão, por 7, da soma das unidades, milhões, bilhões, trilhões etc. menos os milhares, milhares de milhões, milhares de bilhões etc. mais o dobro das centenas, centenas de milhões etc. menos o dobro das centenas de milhares, centenas de milhares de milhões etc. mais o triplo das dezenas, dezenas de milhões etc. menos o triplo das dezenas de milhares, dezenas de milhares de milhões etc.

Assim, o resto da divisão de 365 por 7 é o mesmo que teremos após dividir $5+2.3+3.6=29$ por 7 , e isto é o mesmo que o resto da divisão de $9+3.2=15$ por 7 , e isto é o mesmo que o resto da divisão de $5+3.1=8$ por 7 . Assim, existe um dia a mais além do número inteiro de semanas em um ano (GARNICA; SOUZA, 2018).

Enunciadas as regras relativas aos restos, há indicativos para, dada uma fração ordinária, obter a dízima periódica. No mais, há apenas uma breve indicação, a ser desenvolvida posteriormente, sobre o conceito de involução ${ }^{26}$ e a nota de que os livros tratarão, essencialmente, dos números ordinais posto que, segundo as breves observações de Peirce (GARNICA; SOUZA, 2018), “números cardinais nada mais são do que uma aplicação especial dos números ordinais, como no caso das grandes quantidades”. Nessa afirmação, ele provavelmente está se referindo aos estudos sobre a cardinalidade de conjuntos infinitos como os desenvolvidos por Cantor, Frege e Dedekind, no que se inclui a aritmética dos transfinitos, o que acrescenta uma camada a mais de argumentação sobre a pouca familiaridade do autor com o sistema educacional e as salas de aula reais - sejam as da escola de primeiras letras, sejam aquelas dos cursos de formação de professores - de sua época.

\subsection{Os Manuscritos 168 e 167}

A nota de rodapé inicial desse bloco de textos, incluída por Eisele, dá conta de que o MS 168 é a versão datilografada do MS 167, que é composto por anotações à mão. Ainda que

\footnotetext{
${ }^{26}$ Involução é antônimo de evolução. Em Matemática é termo utilizado para significar um processo relativo à inversão. No caso, trata-se de, dada uma dízima periódica, obter a fração que a gera, posto que o tratamento desenvolvido por Peirce até aqui consistiu em encontrar a dízima periódica tendo sido dada sua forma fracionária
} 
nada seja dito sobre isso, a julgar pelo título, o MS 167 tem exemplos (e exercícios) que não constavam do MS 168 e que, nessa edição do The New Elements of Mathematics, Eisele juntou para formar um único texto, composto por quatro capítulos.

No primeiro capítulo, bastante reduzido, define-se Aritmética (o conhecimento dos números) e Aritmética Prática (o conhecimento de como usar os números). É aqui que se nota o uso da expressão Aritmética Prática, que o próprio Peirce, em outro manuscrito, acredita ser inadequada. Boa parte dos capítulos estão voltados a elaborar conceitos, termos e expressões, como que uma sequência de verbetes, que o autor enuncia buscando as raízes desses vocábulos nas línguas antigas.

Essa introdução, que toma todo o primeiro capítulo, reforça o que, em termos efetivos, na prática das lições propostas, Peirce já havia pontuado, com ênfase, em outros manuscritos: "Duas qualidades devem estar entre nossos objetivos - primeiro a exatidão, depois a eficiência" (GARNICA; SOUZA, 2018). Por eficiência entende-se a agilidade nos cálculos e contagens, para o que o conjunto de manuscritos reserva um grande número de atividades de repetição, com dicas mnemônicas e premiações pelas respostas corretas mais rapidamente dadas pelos alunos. Uma sequência de cinco máximas - visando às necessárias correção e eficiência - são dadas:

I.Não se desgaste, ou melhor, exercite-se de modo calmo e sereno,

II.Pense sobre o que você está fazendo e mantenha afastada de sua mente toda sorte de distração,

III.Nunca confie que um resultado esteja correto no primeiro cálculo. Realize o cálculo uma segunda vez e, se possível, de um modo diferente. Refaça seu trabalho do último passo até o primeiro, ou assegure-se de não ter cometido erros, pois até os melhores aritméticos - ainda que raramente - algumas vezes cometem erros;

IV.Tente ver todo problema segundo uma perspectiva prática: imagine qual poderia ser o resultado, pelo menos um resultado aproximado,

V.Faça suas anotações de modo que, imediatamente, todos possam observar o que você fez, possam ver que a operação correta foi usada e que você a realizou corretamente (GARNICA; SOUZA, 2018).

Numeração - a arte de formar numerais, de dar nomes aos números - é o tema do segundo capítulo. Aqui, a ênfase é, ao que parece, registrar um glossário que, até o final do manuscrito terá verbetes como Aritmética, Algoritmo, Numeral, Decimal, Unidade, Dígito e Notação Arábica. O foco fica na contagem, seja a sequencial, seja ela relativa ao conhecimento das unidades de medição (medidas de tamanho, de massa, de área, de volume e relativas ao uso da moeda).

Esses manuscritos são os mais eruditos de todo o conjunto de textos. Ainda que o conhecimento de Peirce acerca de outras culturas e da Ciência, de modo geral, apareça aqui e ali nos outros manuscritos, aqui ele é onipresente. Um exercício proposto, relativo à contagem 
de feijões, encerra esse capítulo, mas problemas e exemplos dos capítulos subsequentes ${ }^{27}$ vão trazer à cena o movimento dos planetas, dados populacionais e relativos a atividades profissionais e a altura de algumas das principais montanhas do mundo. Reforçando a impressão por nós já anunciada anteriormente, há, nesse manuscrito, nota de Peirce quanto às informações acerca da Geografia da Terra terem sido buscadas no Annnuaire des Longitudes de 1888, o folheto de divulgação do Bureau des Longitudes francês, criado em 1795 (ano III do calendário revolucionário). Esse Anuário, até hoje, divulga e atualiza dados relativos a medidas geofísicas e astronômicas, exatamente o que fazia a Coast and Geodetic Survey, sua congênere americana.

Mais uma vez, ao fim do manuscrito, Peirce recomenda o uso de um recurso didático a ser construído em tamanho grande (para toda classe) e reproduzido no caderno de cada uma das crianças. Trata-se do Quadro Aritmético, similar a um contador:

O seguinte dispositivo é necessário para este capítulo: trata-se de um quadro aritmético, um quadro com uma alça, de forma que ele possa ser pendurado no alto, com 12 fios, em cada um deles correndo nove bolas, as nove bolas de um mesmo fio têm a mesma cor, mas a quinta bola é achatada nos polos, de modo a ter uma protuberância para fora para facilitar a contagem. As cores das bolas nos diferentes fios, começando pelo mais baixo, são: preta, azul, vermelha, verde, amarela, branca, preta, azul, vermelha, verde, amarela, branca.

Uma quantidade de folhas, cortadas em retângulos, do tamanho e formato adequados para colocar um número em cada e com colunas em cujas primeiras linhas, sucessivamente, estão indicados: lakhs de milhão, miríades de milhão, milhares de milhão, centenas de milhão, dezenas de milhão, milhões, lakhs, miríades, milhares, centenas, dezenas, unidades, décimos, centésimos, milésimos. Um quadro negro marcado do mesmo modo. Cadernos de anotações, cuidadosamente quadriculados, seguindo o mesmo padrão das folhas cortadas, mas sem os registros que há nas folhas.

O quadro aritmético, usado com o caderno, é construído segundo o mesmo princípio dos contadores, cada bola representando um contador. Quando elas não forem necessárias serão empurradas para um lado do quadro, e quando elas tiverem um significado serão trazidas para o outro lado. As bolas não possuem registro algum sobre elas, todavia, cada uma corre num um fio distinto, e esses fios são colocados em uma ordem regular: unidades, dezenas, centenas etc. Esses lugares fixos dos fios tornam o quadro um modo mais claro para indicar um número. (O professor explicará o uso do quadro com exemplos) (GARNICA; SOUZA, 2018).

\section{Como conclusão possível}

Com a tradução dos manuscritos e os estudos dessa tradução (feitos sempre em cotejamento com os originais em língua inglesa) aliados a revisões sobre o ambiente sóciocultural-político e educacional do final dos oitocentos, além de um levantamento exaustivo

\footnotetext{
${ }^{27}$ Os capítulos III e IV têm como tema, ambos, a notação arábica e o uso de decimais.
} 
sobre a biografia de Peirce ${ }^{28}$, podem ser registradas algumas compreensões mais panorâmicas acerca de sua Aritmética Elementar.

É importante ressaltar que a hermenêutica de manuscritos inacabados, e bem provavelmente incompletos, dada a dispersão dos originais e o descuido com que foram tratados ao longo da história, é uma tarefa extremamente árdua. Não há, por exemplo, informações mais precisas sobre o que levou Eisele a apresentar os manuscritos na sequência em que ela os apresentou, juntando alguns deles e separando outros ${ }^{29}$. Entretanto, deve-se considerar que apostar numa sequenciação específica, recortando os textos e os encadeando de alguma forma, elaborando um texto menos truncado, visando a alguma coesão, implicaria decisões ainda mais subjetivas, o que Eisele - sensatamente, do nosso ponto de vista - evitou. Não há sequer indicações precisas e mais definitivas de Peirce sobre o que ele julgava minimamente adequado para a composição final. Disso, resulta que temos que lidar com o que está dado: um conjunto de anotações marcado pela lacunaridade, pela repetição de assuntos e pela inexistência de uma sequência inequívoca.

Ainda assim, a apreciação de Eisele quanto a esse conjunto de manuscritos nos parece efusiva demais, já que ela pouco realça as limitações (naturais) de uma interpretação que tem como fonte apenas manuscritos inacabados. Ela destaca, por exemplo, a familiaridade de Peirce quanto às propostas de Klein e com relação às iniciativas de reformulação curricular para o ensino de Matemática que começavam a se tornar mais explícitas no final de século XIX.

Sua obra, segundo Eisele, era moderna, e suas explicações claras e rigorosas, estando nelas embutidas diretrizes avançadas em relação à metodologia de ensino. Talvez isso, com essa ênfase, possa caracterizar a obra matemática de Peirce que, como sabemos, é bastante extensa e foi intensamente estudada e compilada por Eisele nos quatro grandes volumes do The New Elements of Mathematics of C. S. Peirce.

No que diz respeito à Aritmética Elementar, entretanto, ainda que sejam bastante nítidas algumas propostas diferenciadas para o ensino de Matemática, a ênfase na repetição, a ausência de justificativas mais detalhadas e expostas de um modo mais adequado para professores com formação deficitária, a variação do tom na exposição do conteúdo e a

\footnotetext{
${ }^{28}$ Parte desses assuntos é tratada aqui, parte tratada em Souza; Garnica e Salandim (2018).

29 Tanto a tradução quanto as considerações sobre cada um dos manuscritos, neste artigo, respeitam a ordenação proposta por Eisele.
} 
indecisão, mostrada ao longo dos manuscritos, sobre a qual público, efetivamente, os manuscritos se dirigiriam, também marcam distintivamente esse conjunto de textos.

Essas características, talvez, possam ser explicadas tanto pela falta de experiência de Peirce em relação à realidade do sistema escolar americano - que ele sequer frequentou como aluno, posto ter sido, na infância, educado pelo pai - quanto pela personalidade difícil do autor, que enfrentou durante sua vida - mas principalmente quando vivendo às próprias custas, já sem o apoio da figura paterna que havia possibilitado sua entrada em diversos círculos sociais e acadêmicos bastante privilegiados à época - vários problemas financeiros, agravados pela sua saúde frágil, por sua arrogância e pela dificuldade de relacionar-se socialmente e em ambientes profissionais ${ }^{30}$.

Os acertos para a publicação dos manuscritos levariam Peirce a reverter, ao menos em parte, sua difícil situação frente a inúmeros credores, mas sua desorganização não permitiu que ele os concluísse. O que se nota, no que restou desses textos, é um conjunto de anotações gerais, desconectadas, que em boa medida podem ter servido para aplacar por algum tempo as cobranças dos editores que acabaram rescindindo o contrato com o autor.

Os textos, em que ora o autor conversa diretamente com as crianças, ora trata dos conteúdos e propostas de ensino, voltando-se aos professores, parecem sugerir que haveria pelo menos dois enfoques a serem privilegiados: aquele do material didático a ser usado em salas de aula, propriamente dizendo, e o de um material que serviria como um livro do professor, um manual de apoio pedagógico, em linguagem mais coloquial.

Deve ser considerada, também, a possibilidade - aventada pelo próprio Peirce, segundo Eisele - de haver pelo menos dois outros enfoques para a Aritmética Elementar: um relacionado à Aritmética Elementar (tomando elementar, aqui, como inicial, introdutório, básico), propriamente dizendo, e outro relacionado à fundamentação dos conceitos e técnicas envolvidos nessa Aritmética (provavelmente o que Peirce chama de Aritmética Superior ou Avançada).

Por outro lado, são nítidas algumas inovações na mobilização de estratégias criativas para o ensino. Mais particularmente, é notável, em alguns pontos dos manuscritos, a intenção de Peirce de se aproximar da linguagem infantil, de um modo próprio de dizer, lançando mão das rimas, do ritmo, e das histórias infantis. Essas histórias apoiam-se em elementos clássicos como a família, a avó pacienciosa, justa e sábia, a professora e seus alunos, uma casa na

\footnotetext{
${ }^{30}$ Eisele reitera o fato de Peirce e sua extensa produção não terem tido reconhecimento em vida, mas não considera esses dados biográficos como desempenhando algum papel para essa resistência do meio acadêmico.
} 
floresta, e algumas situações curiosas, como a que propõe o resgate de tesouros escondidos ou buscas na mata.

Há um esforço para, nos exemplos e exercícios, trazer elementos da história americana, apresentar informações relativas a uma cultura geral letrada, aproximar as crianças de discussões sobre as novidades tecnológicas e aspectos da geografia, das tradições americanas e de outros países, e da História Geral. Desses tantos elementos, destaca-se o uso de materiais didáticos como ábacos, jogos, quadros, fichas e cartões. É certo que esses recursos precisariam ser retomados, enfatizados e melhor organizados pelo autor e distribuídos em diferentes volumes, mas o que se tem nos manuscritos é mais do que suficiente para assegurar as intenções de Peirce quanto a elaborar pelo menos um texto aquele de um manual didático a ser usado em sala de aula pelas crianças -, digamos, adequado à infância, e tomá-lo como uma inovação educacional em potencial.

\section{Referências}

ANDRADE, M. M.; GARNICA, A.V. M. Invocando Jerônimo e Bárbara: notas sobre o processo de tradução e observações sobre um caso específico - a tradução dos Ensaios de Lacroix. Perspectivas da Educação Matemática, Campo Grande, v. 8, p. 568-586, 2015.

BENJAMIN, W. A tarefa do tradutor. In: CASTELO BRANCO, L. A tarefa do tradutor, de Walter Benjamin: quatro traduções para o português. Belo Horizonte Fale/UFMG, 2008.

BRENT, J. C. S. Peirce: A life. 2. ed. Bloomington And Indianapolis: Indiana University Press, 1998. $412 \mathrm{p}$.

CAMPOS, G. O que é tradução. 1. ed. São Paulo, SP: Editora Brasiliense. 1986.

CARROLL, L. Euclides e Seus Rivais Modernos. 1. ed. São Paulo: Editora da Física: 2015.

ECO, U. Quase a mesma coisa. Tradução de: Eliana Aguiar. 2. ed. Rio de Janeiro: Record, 2014.

EISELE, C. Charles S. Peirce Nineteenth Century Man of Science. Scripta Mathematica 24, p. 305324, 1959.

GARNICA, A.V. M. Peirce's Mathematical Writings: an essay on Primary Arithmetic Books as it relates to Mathematics Education. Revista Brasileira de História da Matemática, Rio Claro, v. 1, n. 2. p. 37-57, out, 2001.

GARNICA, A.V. M., SOUZA, L. J. de. A Aritmética Elementar de Peirce - Tradução e Comentários. Editora UNESP, 2018. (no prelo).

GLEASON, M. L.; DAUBEN, J. W. Eloge: Carolyn Eisele, 1902-2000. Isis, University of Chicago Press, [s.1.], v. 95, n. 4, p. 649-652, dez. 2004.

HOUSER, N. The Fortunes and Misfortunes of the Peirce Papers. Disponível em: <http://www. cspeirce.com/menu/library/aboutcsp/houser/fortunes.htm>. Acesso em: 31 de Maio de 2016. Arisbe 
web site, 1998.

LACROIX, S-F. Ensaios sobre o Ensino em Geral e o de Matemática em Particular. 1. ed. São Paulo: Editora UNESP, 2013.

PEIRCE, C. S. Collected Papers of Charles Sanders Peirce. In: HARTSHORNE, C.; WEISS, P. (Ed.). BURKS, A. W. (Ed.). Harvard University Press, Cambridge, 1931-1958. v. 1- 6, p. 1931-1935; v. 7 - 8, p. 1958.

PEIRCE, C. S. Charles S. Peirce Selected Writings: Values in a Universe of Chance. 1. ed. The Hague: Mouton Publishers, 1958.

PEIRCE, C. S. The New Elements of Mathematics. Editado por C. Eisele. 1. ed. The Hague: Mouton Publishers, v. 4, 1976.

PEIRCE, C. S. Writings of Charles S. Peirce: A Chronological Edition, Volume 1. Indiana University Press, 1982.

PEIRCE, C. S. Charles S. Peirce: the essential writings. Amherst, New York: Prometheus Books, 1998.

SILVA, M. C. L. da, VALENTE, W. R. A Geometria nos primeiros anos escolares: história e perspectivas atuais. 1. ed. Papirus, 2014.

SOUZA, L. J. de; GARNICA, A. V. M; SALANDIM, M. E. M. Dos Manuscritos da Aritmética Elementar de Charles S. Peirce: um cenário sócio-histórico. UFMS-Campo Grande. Perspectivas da Educação Matemática, 2018. (no prelo)

Submetido em 14 de Novembro de 2017. Aprovado em 30 de Janeiro de 2018. 